\author{
Matgorzata Puchowska \\ Zakład Edukacji Wczesnoszkolnej i Przedszkolnej \\ Instytut Pedagogiki \\ Akademia Pomorska w Stupsku
}

\title{
Blaski i cienie życia $w$ internatach szkół jezuickich w II Rzeczypospolitej
}

\begin{abstract}
Małgorzata Puchowska, Positive and Negative Aspects of Life in Jesuit Boarding Schools in the Second Republic of Poland

Jesuit boarding schools did not fulfil only social roles. They were educational institutions shaping discipline, morality and religiousness of their pupils. The monks organized various activities for their students which were conducive for acquiring and consolidating knowledge. Students' time was filled with the review of school material, literary exercises, debates or production of theatre performances. The offer depended on the degree of exclusivity of a given establishment.

In the Second Republic of Poland, there functioned three Jesuit schools for laymen: in Khyriv (Pol. Chyrów), Vilnius and Gdynia. Only the first two ran boarding schools. Both boarding schools offered very good living conditions, and the life of the alumni passed according to a similar, clearly defined day rhythm. The institutions in busy urban Vilnius and peripheral Khyriv were very much different. The educational process used for the boarding students from Vilnius lacked special rigours, which was different from the methods generally accepted at that time. The behaviours of boarding students from Khyriv, in turn, were regulated in the minutest detail by Statutes and regulations and the system of punishments was very elaborate. The schools tried to restore order by the method of overcoming the resistance of the more independently feeling and thinking pupils.
\end{abstract}

Keywords: boarding schools, jesuit schools, Second Republic of Poland

Przyjęcie przez kolegia jezuickie funkcji edukacyjnych i otwarcie się na uczniów świeckich spowodowało, że zakon stopniowo uruchamiał bursy dla ubogiej a utalentowanej muzycznie młodzieży, a z czasem także odrębne jednostki administracyjne, konwikty ${ }^{1}$. Mieszkali w nich synowie ludzi bogatych, szlachetnie urodzonych, sami ponosząc koszty utrzymania ${ }^{2}$. Podstawowe reguły dla konwiktorów spoza zgromadzenia stanowiły,

${ }^{1}$ P. Gach, Konwikt szlachecki, w: Encyklopedia katolicka, t. IX: Kinszasa-Krzymuska, pod red. A. Szostka, B. Miguta i in., Lublin 2002, szp. 790-791; S. Kunowski, Bursa, w: ibidem, t. II: Bar-Centuriones, pod red. F. Gryglewicza, R. Łukaszyka, Z. Sułowskiego, Lublin 1985, szp. 1226-1227.

2 I. Loyola, Konstytucje Towarzystwa Jezusowego, przekł. M. Oleksy, Kraków 1982, s. 141-142. 
że tacy studenci powinni by jednak mieszkać osobno i bez zgody przełożonego nie powinni przebywać z nikim oprócz niektórych osób z Towarzystwa wyznaczonych przez przełożonego ${ }^{3}$.

Konwikty jezuickie pełniły nie tylko funkcje socjalne. Były zakładami wychowawczymi, kształtującymi dyscyplinę, moralność i religijność podopiecznych. Obowiązujący w tych placówkach rytm życia powielał system narzucony nowicjuszom zakonu. Chłopcom organizowano też różne zajęcia sprzyjające zdobywaniu i utrwalaniu wiedzy. Choć konwikty nie realizowały osobnych programów nauczania, czas mieszkańców wypełniały szkolne powtórki, ćwiczenia literackie, dysputy czy przygotowanie przedstawień teatralnych, a oferta edukacyjna zależała od stopnia elitarności placówki.

Otwieranie przez zakon kolejnych konwiktów ${ }^{4}$ wynikało z woli hojnych fundatorów, ale także z własnych doświadczeń, które wykazały sukcesy edukacyjne szkół z internatem przy stosunkowo miernych efektach wychowawczych uzyskiwanych w samych kolegiach $^{5}$. Jeszcze podczas obrad I Kongregacji Generalnej w 1558 r. przyjęto zasadę, że prowadzenie szkół z internatem stanowić może jedynie wyjątek od przyjętych reguł, ale z czasem członkowie Towarzystwa nie tylko nie wzbraniali się przed podjęciem obowiązku prowadzenia takich placówek, ale wręcz do tego zachęcalí ${ }^{6}$.

W Rzeczypospolitej apologia konwiktu znalazła odbicie między innymi na scenie teatru uczniowskiego. W monologach Philopater Grzegorza Knapskiego ubolewano nad losem dzieci zamożnych i ustosunkowanych rodziców, którym otoczenie ułatwia próżniacze życie, odciąga od nauk, wskazuje złe drogi, na które młodzież łatwo sprowadzić. Mieściła się w tym dyskretna propaganda edukacji w szkołach z internatem, których mury i opiekunowie chronią młodzież przed światem zewnętrznym, przed natrętnymi pochlebcami, przed pokusami życia dorosłych, a nawet przed nie zawsze pożądanymi wpływami rodziny?

Cele podobne do tych sprzed wieków przyświecały też twórcom Zakładu NaukowoWychowawczego w Chyrowie. Jego koncepcja zakładała lokalizację przy miasteczku matym raczej, niż w jakim mieście większym, a to nie tylko dla większej taniości, ale szczególniej dlatego, że będąc u siebie, będziemy mogli młodzieży nam powierzonej dać odpowiednia swobodę dla rozwoju tak fizycznego, jak duchowego równie korzystna, bez wystawiania jej na niebezpieczeństwa, na jakie większe centra obecnie tak bardzo nara$\dot{z} a j a^{8}$.

${ }^{3}$ Ibidem, s. 142 .

${ }^{4}$ Jeszcze w początkach XVII w. placówki te należały do rzadkości, ale w momencie kasaty funkcjonowało już 171 konwiktów jezuickich.

5 J. W. O’Malley, op. cit., s. 345. Miernikiem sukcesów mogła być liczba powołań zakonnych.

${ }^{6}$ Monumenta Paedagogica Societatis Iesu, ed. L. Lukács S.I., t. III: (1557-1572), Romae 1974, s. 7.

${ }^{7}$ L. Winniczuk, Szkoła jezuicka $w$ zwierciadle szkolnego teatru jezuickiego, w: idem, Od starożytności do współczesności, Warszawa 1981, s. 238-239.

${ }^{8}$ Rkps APPP 1172-I, Okólnik ks. H. Jackowskiego z 15 VIII 1883, [druk] nr 4, s. 1. 
Placówkę otwarto w roku 1886. Potocznie nazywano ją konwiktem, bo choć składała się ze szkoły i internatu, podział ten był jedynie formalny. Zakład mógł pomieścić nawet ponad 500 konwiktorów. Tylko co dwudziesty uczeń mieszkał poza konwiktem9.

W II Rzeczypospolitej funkcjonowały w sumie trzy szkoły jezuickie dla świeckich. Gimnazjum w Wilnie pierwszych uczniów przyjęło 36 lat po Chyrowie. W roku 1924 uruchomiono tam również internat ${ }^{10}$. Mieścił się w neoklasycznym Pałacu Brzostowskich, przylegającym do kościoła św. Kazimierza. Mieszkało w nim średnio 10\% uczniów, a wśród nich, co interesujące, zdarzali się także chłopcy z domów wileńskich ${ }^{11}$. Trzecia szkoła jezuicka, gimnazjum w Gdyni, rozpoczęła pracę w 1937 r. i nie prowadziła własnego internatu.

Konwikty w wielkomiejskim Wilnie i peryferyjnym Chyrowie bardzo się różniły. Także zewnętrznie. Wileński internat przy Wielkiej 64 wtapiał się w ogólną zabudowę ulicy. Drugi wchodził w skład gigantycznego obiektu, którego 327 sal i pomieszczeń o różnym przeznaczeniu łączyły korytarze o długości 1980 metrów ${ }^{12}$. Dochodziły do tego budynki gospodarczo-użytkowe, dzięki którym zakład był samowystarczalny ${ }^{13}$. Czynił imponujące wrażenie. Monumentalizm obiektu - jedynym, pochodzącym z XVIII w. przykładem jezuickiego budynku szkolnego o podobnych rozmiarach jest wiedeńskie Theresianum - wyrażał ,triumfalny powrót zakonu przywróconego do istnienia i odnawiającego swe pedagogiczne zadanie” oraz wolę „ukazania tradycji jezuickich gimnazjów z ich dawnym programem", co podkreśla chociażby fakt zbudowania teatru ${ }^{14}$. Nic dziwnego, że pierwsze zetknięcie z olbrzymim, zakratowanym gmachem tak głęboko zapadło w pamięć przyszłych pensjonariuszy, że we wspomnieniach określają je jako

${ }^{9}$ L. Grzebień, Wprowadzenie, [do:] Chyrowiacy. Słownik biograficzny wychowanków Zakładu NaukowoWychowawczego OO. Jezuitów w Chyrowie, 1886-1939, Kraków 2000, s. 9. Zob. też: J. Niemiec, Zakład Naukowo-Wychowawczy Ojców Jezuitów w Chyrowie 1886-1939, Rzeszów-Kraków 1998, s. 147-153.

${ }^{10}$ Działał przez dwa lata. W roku szkolnym 1927/28 otwarto go ponownie. J. Poplatek, Pierwsze lata Gimnazjum OO. Jezuitów w Wilnie, w: I Sprawozdanie Dyrekcji Gimnazjum OO. Jezuitów w Wilnie za rok szkolny 1927/28, Wilno 1928, s. 3-38.

${ }^{11}$ Najwięcej konwiktorów (68) było w roku szkolnym 1930/31. A. Houwalt, Konwikt, w: Gimnazjum Ojców Jezuitów w Wilnie w latach 1922-1940 (monografia), pod red. R. Cybulskiego, A. Houwalta, J. Jasieńskiego i in., Bydgoszcz 2000, s. 133-134.

12 Jego dokładny opis zob. J. Sas, Konwikt chyrowski w latach 1886-1911, w: XVIII Sprawozdanie Zaktadu Naukowo-Wychowawczeego OO. Jezuitów w Bąkowicach pod Chyrowem za rok szkolny 1911, Przemyśl 1911, s. 27-28; T. Bzowski, Konwikt chyrowski, Chyrów 1935, s. 33. Zob. też: J. Sas, Początki chyrowskiego kolegium, „Nasze Wiadomości” t. 2, (1906-1909), s. 344-349; „Przegląd Chyrowski” z. 180 (1936); XLII Sprawozdanie Dyrekcji Zakładu Naukowo-Wychowawczeego OO. Jezuitów w Bąkowicach pod Chyrowem za rok szkolny 1935/36, Bąkowice pod Chyrowem 1936, s. 54-581; B. Augustyn, Dzieje konwiktu oo. Jezuitów w Chyrowie, „Bieszczad. Rocznik Towarzystwa Opieki nad Zabytkami. Oddział w Michniowcu” nr 4, Ustrzyki Dolne 1997, s. 78. Porównywalnym zakładem było też kolegium w Bejrucie. A. Gluzińska, Zakład oo. Jezuitów pod wezwaniem św. Józefa w Bąkowicach pod Chyrowem oraz twórcy jego architektury, Kraków 1998, mps APPP 5999, s. 96.

13 Zob. J. Sas, Początki..., s. 233-235, 344; idem, Odznaczenie chyrowskiego konwiktu na Wystawie Przyrodniczo-Lekarskiej we Lwowie, „Nasze Wiadomości” t. 1, (1904-1906), s. 417-418; M. Żwawa, Zaplecze materialne Gimnazjum OO. Jezuitów w Bąowicach pod Chyrowem i jego wpływ na proces dydaktyczno-wychowawczy, Kraków 1997 (mps Biblioteki Wydziału Filozoficznego Towarzystwa Jezusowego w Krakowie), s. $92-93$.

${ }^{14}$ M. Gutowski, Architektura szkół średnich w Polsce w okresie zaborów, Białystok 1991, s. 93. 
przytłaczające i przerażające. Bywało, że nie mogli powstrzymać łez przy pożegnaniu, niektórzy myśleli o ucieczce ${ }^{15}$. Pamiętajmy, że do konwiktu przyjmowano chłopców, którzy ukończyli ósmy rok życia, a nie przekroczyli czternastego. Przeżywali bardzo rozstanie z rodziną. Od chwili przekroczenia zakonnej furty miały minąć nierzadko miesiące do spotkania $\mathrm{z}$ najbliższymi ${ }^{16}$. Nawet, jeśli w konwikcie przebywali bracia, wolno im było rozmawiać tylko w określone dni na dużej przerwie ${ }^{17}$. Doskwierała „samotność dziecięcej bezradności zaskoczonej nowością swej życiowej sytuacji, odcięciem od domu, z którym była ona dotychczas związana codziennym węzłem miłości i zaufania"18

Zakład w Chyrowie nawiązywał do doświadczeń jezuickich kolegiów szlacheckich, głównie ekskluzywnych placówek francuskich doby Oświecenia, oraz współczesnych mu szkół w Paryżu, Londynie, Stonyhurst, Tronchienns, podwiedeńskim Kalksburgu i Feldkirch ${ }^{19}$, wzorem których kształcił w swych murach elity urodzenia i elity finanso$w^{20}$. Wychowankowie, wywodzący się przeważnie z rodów ziemiańskich lub dobrze sytuowanych rodzin urzędniczych, mieli w przyszłości objąć najważniejsze stanowiska w życiu politycznym, gospodarczym i kulturalnym ${ }^{21}$. Gimnazjum chyrowskie uważane było za jedną z najlepszych tego typu szkół w Polsce ${ }^{22}$. Bardzo wysoki poziom nauczania, przygotowanie merytoryczne i metodyczne kadry pedagogicznej, stan pomocy dy-

15 Zob. np: Z. Domański, Sercem przywiązany.., w: Chyrowiacy, pod red. L. Grzebienia, Kraków 1990, s. 24; L. Dunin, Tego mundurka było mi żal..., ibidem, s. 17; W. Krawczyński, Chyrowskie reminiscencje, ibidem, s. 64; A. Paygert, Po pięćdziesięciu latach, ibidem, s. 74; J. Starnawski, Takim był Chyrów, ibidem, s. 48, 54; A. Udrycki, Wspomnienie sprzed 67 lat, ibidem, s. 31.

${ }^{16}$ Chłopcy często pozostawali w konwikcie nawet podczas Bożego Narodzenia czy Świąt Wielkanocnych. J. Garliński, Świat mojej pamięci, Warszawa 1992, s. 66.

${ }^{17}$ I. Hirszel, Życie piękne i radosne, w: Chyrowiacy, s. 29.

18 A. Paygert, op. cit., s. 74.

19 Pamiątka dwudziestopięciolecia chyrowskiego konwiktu 1886-1911, Chyrów 1911, s. 25; E. Kula, M. Pękowska, Gimnazjum chyrowskie i jego wychowankowie, w: Galicja i jej dziedzictwo, T. 3: Nauka i oświata, pod red. A. Meissnera, J. Wyrozumskiego, Rzeszów 1995, s. 199. Zob. też: 100 Jahre Kollegium Kalksburg. Festschrift 1956, Wien 1956.

${ }^{20}$ K. Puchowski, Collegium Nobilium Stanisława Konarskiego a elitarne instytucje wychowawcze zakonów nauczajacych w Europie, „Wiek Oświecenia” t. 20/2004, s. 25-36. O chyrowskiej placówce mówiono jako o współczesnym Collegium Nobilium. Zob.: A. Paygert, op. cit., s. 72. Na elitarny charakter konwiktu wskazują również prowadzone w nim lekcje jazdy konnej, szermierki czy tańca.

${ }^{21}$ Zapewniały o tym Ustawy i przepisy Zakładu Wychowawczo-Naukowego Tow. Jez. w Chyrowie pod wezwaniem św. Józefa, Chyrów 1896, s. 3 oraz wydania następne z lat 1899, 1905, 1911, 1934, 1937. Zob. też: Przepisy uczniów kl. VIII Zakładu Wychowawczo-Naukowego Św. Józefa w Bąkowicach pod Chyrowem, Chyrów 1896, s. 3; Konwikt Chyrowski w ubiegtym dziesięcioleciu, w: XXXIV Sprawozdanie Zakładu NaukowoWychowawczego OO. Jezuitów w Bąkowicach pod Chyrowem za rok szkolny 1927/28, Chyrów 1927/28, s. 47; Chyrowiacy. Stownik biograficzny wychowanków Zakładu Naukowo-Wychowawczego OO. Jezuitów w Chyrowie, 1886-1939, oprac. L. Grzebień, J. Kochanowicz, J. Niemiec, Kraków 2000, passim.

22 L. Bykowski, Stan naukowych gabinetów i pracowni w naszych szkołach średnich, „Muzeum” R. 25 (1910), t. II, s. 38-40; S. Janelli, Stan szkół średnich prywatnych w kraju, „Muzeum” R. 29 (1913). t. II, s. 5; T. Włodarczyk, Szkoły prowadzone przez zakony męskie w Polsce ze szczególnym uwzględnieniem szkoły chyrowskiej (1918-1939), „Studia z Dziejów Kościoła Katolickiego” 5 (1967), nr 8, s. 165-166. 
daktycznych i osiągane wyniki kształcenia, ale także elitarność placówki przyniosły jej miano polskiego Eton ${ }^{23}$.

Również posiadające pełne prawa państwowe Gimnazjum św. Kazimierza w Wilnie uchodziło za ekskluzywne. Wymagania stawiane przez szkołę były wysokie ${ }^{24}$. Prestiż placówki opierał się też na pozytywnej opinii o doświadczeniu edukacyjnym zakonu oraz stosowanych przez niego zasadach, metodach i żelaznej dyscyplinie ${ }^{25}$. Renoma, jaką cieszyli się jezuici, sprawiła, że mieszkańcy Wilna chętnie umieszczali tu swoich synów gimnazjum było jedną z sześciu największych szkół w mieście ${ }^{26}$ - zaś konwiktorzy wywodzili się $\mathrm{z}$ różnych stron kraju. Przeważali chłopcy $\mathrm{z}$ rodzin ziemiańskich i urzędniczych ${ }^{27}$.

Oba konwikty oferowały bardzo dobre warunki bytowe. Młodzież z zakładu chyrowskiego podzielona była klasami na oddziały zwane dywizjami, którymi opiekowali się prefekci. Podział ten obowiązywał także w jadalni i kaplicy ${ }^{28}$. Każda z dziewięciu dywizji miała swoją obszerną sypialnię, w której stało nawet 100 łóżek. W tych koszarowych warunkach namiastkę intymności zapewniały wysokie, drewniane parawany. Do konwiktora należał też stolik-szafka, na którym stała miednica. „W parawanie była półka i wieszadło na ubranie. Tworzyło to takie własne gospodarstwo"22. Poszczególne dywizje miały dodatkowo swoją salę do nauki, salę rekreacyjną, a nawet boisko. Wspólnie użytkowano natomiast trzy korty tenisowe i pływalnię ${ }^{30}$. Chłopcom zapewniano świetne warunki sanitarne z bieżącą ciepłą i zimną wodą, opiekę medyczną i cztery urozmaicone posiłki dziennie ${ }^{31}$.

Mieszkańcy internatu przy ulicy Wielkiej również nie mogli narzekać na swoje lokum. Na drugim piętrze trzypoziomowego pałacu mieściły się cztery sypialnie, garderoby i infirmeria. Pierwsze piętro zajmowały dwie wielkie sale, w których odrabiano lekcje przy indywidualnych, ustawionych rzędami biurkach, dwie sale rekreacyjne, ogromna, oszklona i opalana zimą weranda, szatnia i łazienka. Na parterze znajdowała się kaplica oraz pokoje do nauki dodatkowych języków i muzyki, a w podziemiu refektarz, w któ-

23 A. Nowaczyński, Dzień w Chyrowie, „Mały Dziennik” 18 X 1936.

${ }^{24}$ W. Rogoziński, Warunki nauki, w: Gimnazjum Ojców Jezuitów..., s. 85.

${ }^{25}$ W. Rogoziński, Uczniowie, w: Gimnazjum Ojców Jezuitów..., s. 119-120.

${ }^{26}$ R. Cybulski, Szkoły średnie ogólnoksztatcace w Wilnie w latach 1915-1939, w: Kultura międzywojennego Wilna. Materiaty z konferencji w Trokach (28-30 VI 1993), pod red. A. Kieżuń, Białystok 1994; Szkoty Rzeczypospolitej Polskiej w roku szkolnym 1930/31, pod red. M. Falskiego, Warszawa 1933.

27 Zob. I Sprawozdanie Dyrekcji Gimnazjum OO. Jezuitów w Wilnie....

${ }^{28}$ III Sprawozdanie Zakładu Naukowo-Wychowawczego OO. Jezuitów w Bąkowicach pod Chyrowem za rok szkolny 1896, Przemyśl 1896; T. Bzowski, op. cit., s. 56-57.

${ }^{29}$ L. Dunin, Tego mundurka byto mi żal..., s. 19

30 J. Sas, Początki..., s. 223-228. O kolejnych modernizacjach konwiktowego budynku zob. J. Niemiec, op. cit., s. 66-78.

31 F. Bubieński-Bubeniczek, Pamiętnik, rkps Archiwum Prowincji Polski Południowej Towarzystwa Jezusowego w Krakowie (dalej: APPP) 2470, k. 533-567; L. Dunin [Sulgostowski], Pamiętniki, t. 1, rkps APPP 4344, s. 21; L. Dunin, Tego mundurka było mi żal..., s. 18; Program Zakładu naukowo-wychowawczego OO. Jezuitów pod wezwaniem św. Józefa w Bąkowicach pod Chyrowem, Chyrów 1938, [z dodatkiem:] Koszty nauczania i utrzymania w Zakładzie Chyrowskim. Zob. też: J. Niemiec, op. cit., passim. 
rym żywiono smacznie i obficie ${ }^{32}$. Prócz boiska jezuici wileńscy nie posiadali jednak własnych terenów sportowych.

Za mieszkanie, wyżywienie, opiekę medyczną i pralnię rodziny konwiktorów uiszczały wysokie czesne. W Wilnie za jednego ucznia trzeba było zapłacić miesięcznie 90 złotych za internat i około 30 złotych za szkołę. W analogicznym okresie koszt pobytu chłopca w zakładzie chyrowskim wynosił około 165 złotych, a więc dużo więcej niż połowa średniej pensji urzędniczej. W obu placówkach dochodziły do tego różnego rodzaju opłaty dodatkowe, np. coroczne wpisowe, materiały do zajęć praktycznych, fundusz teatralny czy biblioteczny. Osobno płacono też za ponadprogramowe lekcje muzyki czy języków. Sporą sumę musiano przeznaczyć na tak zwaną wyprawkę, w tym na podkreślający elitarny charakter szkoły mundurek ${ }^{33}$.

W zamian za to podejmowano się w Chyrowie „wychować i umysłowo wykształcić godnych i pożytecznych dla rodzin, kraju i Kościoła członków"34, dać młodzieży podstawe petnego rozwoju kulturalnego, przygotować ja do czynnego udziału w życiu zorganizowanego $w$ ramach państwowych spoleczeństwa oraz przygotować do studiów wyż$s z y c h^{35}$.

Życie wychowanków przebiegało według ściśle określonego rytmu dnia, który zakładał pobudkę o 5.30 zimą i 5.15 latem $^{36}$. Konwiktorów budził dzwonek, klaśnięcie i zawołanie prefekta Laudetur Jesus Christus. Chłopcy czynili znak krzyża i natychmiast wstawali, odmawiając krótką modlitwę przy łóżku. Ubierali się i po pięciu minutach, na kolejny znak rozpoczynali toaletę. Trzeci znak przypominał o jej zakończeniu, czwarty był sygnałem do wyjścia na poranną mszę. Po niej następowało śniadanie, czas na przygotowanie się do szkoły w sali cichej nauki, wreszcie lekcje przedpołudniowe. Po obiedzie udawali się na rekreację lub lekcje prywatne, by znów wrócić na godzinę do sal naukowych, a potem do szkoły. Zakończenie lekcji oznaczało nastanie czasu podwieczorku i dwugodzinnej nauki własnej. Kolację jadano o godzinie 19.00. Po niej krótka rekreacja, godzinna nauka i wreszcie o 21.00 uczniowie kładli się do łóżek ${ }^{37}$.

Zachowanie konwiktorów aż po najdrobniejsze szczegóły regulowały Ustawy i przepisy ${ }^{38}$. Nie pozostawiały one żadnych wątpliwości, jak w danym miejscu i okolicznościach powinien postąpić. Inne reguły obowiązywały w czasie pobytu w kaplicy, inne na korytarzu; odrębnych zasad zachowania przestrzegano w jadalni, w sali rekreacyjnej, na boisku szkolnym, w infirmerii czy podczas przechadzki. Podczas pobytu w sali naukowej

\footnotetext{
${ }^{32}$ A. Houwalt, op. cit., s. 136.

33 Ibidem, s. 133-136; J. Niemiec, op. cit., s. 153-160.

${ }^{34}$ Ustawy i przepisy..., Chyrów 1899, s. 3; Przepisy uczniów kl. VIII..., Chyrów 1896, s. 3; Konwikt Chyrowski w ubieglym dziesięcioleciu, s.47.

35 Statut Prywatnego Męskiego Gimnazjum OO. Jezuitów w Wilnie, [przedruk w:] Gimnazjum Ojców Jezuitów..., s. 494-497.

${ }^{36}$ Tę wczesną porę wstawania kilkakrotnie, ku zadowoleniu konwiktorów, przesuwano. Zob. J. Niemiec, op. cit., s. 165 .

${ }^{37}$ F. Bubieński-Bubeniczek, op. cit.; L. Dunin, Tego mundurka było mi żal..., s. 19; A. Paygert, op. cit., s. 74-75; Ustawy i przepisy Zakładu Wychowawczo-Naukowego Tow. Jez. w Chyrowie pod wezwaniem św. Józefa, Chyrów 1911, ss. 6, 11-30. Zob. też: J. Niemiec, op. cit., s. 164-172. Por. A. Houwalt, op. cit., s. 137-138.

38 Ustawy i przepisy..., Chyrów 1896 i wydania następne.
} 
Jeżeli [chłopiec] chciat wyjść do WC podnosit rękę z dłonia otwarta, prefekt uważat, by zbyt dużo chłopców tam nie poszło, czy ci, którzy wyszli wrócili $i$ wtedy na znak pozwolenia skiną głowa. Chłopiec $w$ milczeniu wychodzit. W młodszych klasach, nawet jeżeli chłopiec chciat otworzyć szufladę od stolika $i$ wyjać potrzebne przybory do nauki, podnosit do góry rękę z zamknięta dłonią, otwierat ją i zamykał, dopóki prefekt nie skinał mu głowa. [...] Jeśli po otrzymaniu pozwolenia, chłopiec grzebał w szufladzie, podchodzit prefekt [...], by zobaczyć co robi i nakazywat zamknięcie i podjęcie nauki. Jeśli chłopiec chciat podejść do kolegi, by pożyczyć od niego np. pióro [...] szedt po cichu, często na palcach do prefekta, przedstawiat swoja prośbę i otrzymywat $w$ zależności od potrzeby pozwolenie lub nie. Jeśli pobyt u kolegi trwat zbyt dtugo i zaczęła się pogadanka, prefekt podchodził do obydwóch, uspokajał $i$ odsyłał przybysza na swoje miejsce ${ }^{39}$.

Szeregiem nakazów i zakazów objęty był każdy pobyt konwiktora poza murami zakładu. Warto dodać, że w Chyrowie wyjście możliwe było wyłącznie po uzyskaniu zgody rektora bądź prefekta generalnego i tylko w towarzystwie osób dorosłych. Nie wolno było w tym czasie wstępować do sklepów, restauracji, kawiarni czy cukierni. Nawet rodzice mieszkający w okolicznym miasteczku zabierali swych synów na spacery jedynie w pierwszą i trzecią niedzielę miesiąca ${ }^{40}$. Chłopcy mogli tylko zazdrościć gimnazjalistom z Wilna. Tamtejsi konwiktorzy korzystali z dużo większej swobody: bywali na obiadach u krewnych i znajomych rodziny, często przebywali też od południa dnia przedświątecznego aż do końca dnia następnego w gościnie w wileńskich bądź podwileńskich domach kolegów ${ }^{41}$.

Do dziś wiele emocji budzi stosowany przez jezuitów system wychowawczy. Ten temat obecny jest niemal w każdym konwiktorskim wspomnieniu. Chłopcy zdecydowanie nie byli rozpieszczani. Wyróżniających się zachowaniem nagradzano jedynie pochwałą, by nie popadli w próżność, egoizm i zarozumialstwo. Słowa uznania wyrażane podczas publicznej klasyfikacji padały bardzo oszczędnie i może właśnie dlatego mobilizowały do współzawodnictwa ${ }^{42}$.

Od wychowanków jezuickich oczekiwano ścisłego przestrzegania regulaminu, grożąc, że wykroczenia, które z karnościa Zakładu się nie zgadzaja, bezwzględnie karane będa wydaleniem, nawet $w$ ciagu roku szkolnego. Określono przy tym rodzaje „występków" pociągających za sobą najwyższe konsekwencje. Były to: mowy i czyny obrażajace religie św., rozmowy i uczynki przeciwne moralności, rozmyślne powstawanie przeciw przełożonym, ciagłe przekraczanie ustaw konwiktowych i niepostuszeństwo, stałe i niepoprawne zaniedbywanie się w naukach, gorszenie, uwodzenie lub krzywdzenie innych kolegów $w^{43}$.

39 T. Błaszkiewicz, Wspomnienia z Chyrowa z lat 1927-1935, rkps. Cyt. za: J. Niemiec, op. cit., s. 167.

40 Ustawy i przepisy..., Chyrów 1899, s. 31-34.

${ }^{41}$ A. Houwalt, op. cit., s. 138.

42 Ratio instituendae iuventutis in Convictu Chyroviensi S. J., Żółkieviae 1903, s. 4-6.

${ }^{43}$ Ustawy i przepisy..., Chyrów 1899, s. 5. Usunięcie z zakładu mogły też powodować różne młodzieńcze, nieprzemyślane figle. Zob.: A. Paygert, op. cit., s. 73. 
W przeciwieństwie do nagród, system kar w Chyrowie był bardzo rozwinięty. Za niesubordynację wychowanka czekało upomnienie, ale czasami musiał: milczeć, uczyć się $w$ czasie odpoczynku lub $w$ refektarzu przez kwadrans lub pót godziny, uczyć się w czasie wolnym, być pozbawionym drugiego śniadania lub podwieczorku, być pozbawionym jednej potrawy przy obiedzie lub śniadaniu, uczyć się w szkole podczas odpoczynku w obecności Profesora, stać w kacie przez jakiś krótki czas, przez kilka dni być wyłaczonym z korzystania z odpoczynku w bibliotece, być odsuniętym od jakiejś zaba$w y^{44}$. Kary powyższe mogły być przedłużane, a szczególnie niezdyscyplinowanym groziło oddzielenie od wspólnego mieszkania, pozbawienie przechadzki lub całego posiłku ${ }^{45}$. Jednak arsenał środków dyscyplinujących na tym się nie kończył. W Chyrowie golono głowy $^{46}$ i bito $^{47}$. Potwierdzenie stosowania kar cielesnych znajdujemy w wielu wspomnieniach, jedno wszakże zasługuje na baczniejszą uwagę:

Po kilku miesiacach pobytu $w$ Zakładzie wszyscy już wiedzieliśmy, że gdy opiekun klasy napisze po łacinie kilka stów na karteczce i każe udać się z nią do Ojca Generalnego [...], ten wymierzy delikwentowi kilka uderzeń trzcinka. Uderzenia były bolesne, ale nie na tym kończyła się sprawa ${ }^{48}$. Konwiktor musiał po powrocie publicznie pocałować wychowawcę w rękę i podziękować za słusznie wymierzone razy. W razie odmowy, nauczyciel gumową rurką, zwaną potocznie żmijką uzupetniał wypłatę Generalnego ${ }^{49}$.

Po każdym semestrze do pokoju cichej nauki przychodził prefekt. Wszyscy konwiktorzy musieli wtedy siedzieć sztywno z twarzami przed siebie, a on wyczytywał nazwiska chłopców, którym należała się wypłata za złe postępy $w$ nauce lub za jakieś wybryki. Wyczytany szedt na sam koniec sali i tam [...] odbierat porcję kijów ${ }^{50}$.

Stosowano też karę polegającą na nakładaniu na głowę źle uczącego się lub krnąbrnego chłopca szermierczej maski. Na piersiach zawieszano mu karteczkę z napisem „Jestem osłem" i tak kazano chodzić przez kilka dni. Pamiętnikarz, świadek takiej sceny, dodaje: Przerażone, petne męki oczy tego chłopca dziś jeszcze widzę ${ }^{51}$.

Interesujący przykład konsekwencji przekroczenia konwiktowego regulaminu odnajdujemy we wspomnieniach absolwenta jezuickiej placówki w Kalksburgu, bliźniaczej

${ }^{44}$ Ratio instituendae iuventutis..., s. 76.

45 Ibidem.

46 J. Starnawski, op. cit., s. 50.

47 Zapis o stosowaniu kar cielesnych znajdujemy już w Ratio atque Institutio Studiorum SJ, czyli Ustawa Szkolna Towarzystwa Jezusowego (1599), wstęp i oprac. K. Bartnicka, T. Bieńkowski, Warszawa 2000 , s. 112. Zob. też J. Kochanowicz, Zasady dotyczace kar cielesnych $w$ pierwszych kolegiach jezuickich, w: W stużbie historii nauki, kultury i edukacji. Księga pamiątkowa dedykowana Prof. Lechowi Mokrzeckiemu z okazji jubileuszu pięćdziesięciolecia pracy zawodowej, red. R. Grzybowski, T. Maliszewski, Gdańsk 2006, s. 172-183. „Pedagogika bicia” stosowana była konsekwentnie także później, zob. I. Kadulska, Kłopoty uczniowskiego mundurka. O codzienności w oświeceniowej szkole, w: Między barokiem a oświeceniem. Radości i troski dnia codziennego, praca zbior. pod red. S. Achremczyka, Olsztyn 2006, s. 330-340. Zdarzały się też przypadki znęcania nad uczniami, zob. S. Bednarski, Upadek i odrodzenie szkół jezuickich w Polsce. Studium z dziejów kultury i szkolnictwa polskiego, Kraków 1933, s. 395-397.

48 J. Garliński, op. cit., s. 60.

49 Ibidem.

${ }^{50}$ Ibidem.

51 Ibidem, s. 61. 
w stosunku do Chyrowa. Oto, czternastolatek niestarannie oczyścił obcasy swoich butów. Przewinienie to musiał odpokutowywać przez trzy dni. Na ten okres pozbawiono go połowy porcji śniadaniowej, a w refektarzu musiał siedzieć przy osobnym stoliku. Nakazano mu też ścisłe milczenie i zabroniono uczestnictwa w rekreacji. Kiedy koledzy grali w piłkę, on musiał maszerować wzdłuż ogrodzenia ${ }^{52}$.

Godne podkreślenia, że w żadnym z wileńskich wspomnień nie pojawia się informacja o podobnych praktykach ${ }^{53}$. Jest to tym ciekawsze, iż nauczyciele i prefekci zakonni z Chyrowa okresowo pracowali także w Wilnie ${ }^{54}$. Tu jednak $w$ przypadkach bardziej ważkich przewinień następowała poważna rozmowa z prefektem [...]. W innych sytuacjach ojcowie znakomicie potrafili być zgoła partnerscy $[\ldots]^{55}$.

W Ustawach podkreślono, że w wypełnianiu regulaminu nie należy kierować się jakimś marnym i niewolniczym strachem lub obawa kary, lecz szczerym przywiazaniem, ufnością ku przełożonym i poczuciem chrześcijańskiego obowiązku ${ }^{56}$. Owo zaufanie było, jak widać dość jednostronne, skoro w konwikcie istniała pełna kontrola korespondencji uczniowskiej ${ }^{57}$. Cały ten reżim łagodniał nieco w stosunku do uczniów najwyższej klasy. Rozumiejąc potrzebę przygotowania się do matury, dawano chłopcom więcej swobody w gospodarowaniu czasem przeznaczonym na rekreację. Trudno jednak pojąć przesłanki decyzji zezwalającej najstarszym konwiktorom (z klasy VII i VIII) na palenie papierosów ${ }^{58}$.

We wszystkich placówkach jezuickich w formowaniu właściwych postaw moralnych, w eliminacji negatywnych wpływów bardzo dużą rolę przypisywano praktykom religijnym. Zaznaczyć należy, że w badanym okresie nauczanie religii w szkołach polskich było obowiązkowe. Przepisy wymagały też udziału uczniów w nabożeństwach, rekolekcjach i przystępowania do sakramentów ${ }^{59}$. A jednak nawet pomiędzy placówką chyrow-

\footnotetext{
52 A. Krügelstein, Schuld und Sühne, w: 100 Jahre Kollegium Kalksburg..., s. 58-60.

${ }^{53}$ O biciu, które nie doszło do skutku, wspomina jedynie H. Roo, Bójka w klasie, w:, Gimnazjum Ojców Jezuitów..., s. 286. Z opisu wynika, że dyrektor placówki trzymał w biurku „łapkę z trzema skórzanymi, wąskimi paskami”. Nie została ona jednak nigdy użyta. Posłowie [do:] Wspomnienia uczniów, w: Gimnazjum Ojców Jezuitów..., s. 289. Pod koniec lat dwudziestych Prowincjał zakazał stosowania kar cielesnych. W Chyrowie jednak nadal z nich korzystano. Tę informację autorka uzyskała podczas wywiadu z Olgierdem Niewodniczańskim (Bolesławiec Śląski, 11 października 1995), konwiktorem w latach 1930-1933.

54 Byli to m.in. Michał Barglewski, Antoni Bieleń, Władysław Błaszczyk, Władysław Chmura, Witold Czapliński, Ignacy Dubaj, Leon Hobot, Zygmunt Jakubowski, Henryk Kitowski, Józef Konewecki, Kazimierz Konopka, Józef Kościsz, Antoni Kozłowski, Jakub Krysa, Szczepan Machnicki, Bogusław Mączka, Henryk Mroczka, Ignacy Opioła, Józef Pachucki, Maksymilian Piechocki, Władysław Rejowicz, Józef Sawicki, Jan Sobaś, Stanisław Sowa, Edmund Stabryła, Franciszek Tokarz, Stanisław Tomkiewicz, Ignacy Turek, Jan Waligóra, Władysław Zabdyr.

55 A. Houwalt, op. cit., s. 142. Zob. też: Statut Prywatnego Męskiego Gimnazjum OO. Jezuitów w Wilnie, Wilno 1934, [przedruk w:] Gimnazjum Ojców Jezuitów..., s. 494- 497.

56 Ustawy i przepisy..., Chyrów 1899, s. 4; Przepisy uczniów kl. VIII..., Chyrów 1896.

57 „Wszelkie zaś listy, tak te, które sami [konwiktorzy] piszą, jak i te, które otrzymują, przechodzić wprzód mają przez ręce przełożonego. Zatem oddawać należy listy niezapieczętowane ks. Prefektowi”. Ustawy i przepisy..., Chyrów 1899, s. 7.

58 J. Starnawski, op. cit., s. 51.

59 Zob. Ustawy i rozporządzenia obowiązujące w galicyjskich szkołach średnich, zestawił H. Kopia, Lwów 1900, s. 12-13.
} 
ską a wileńską występowały ogromne różnice. Najbardziej widocznym ich przejawem była częstotliwość obowiązkowych mszy. W Wilnie uczniowie chodzili do kościoła w każdą niedzielę i święto. W Chyrowie, gdzie wychowanie religijne stawiano na pierwszym miejscu, dzień rozpoczynał się od wizyty w kaplicy ${ }^{60}$. Takie poranne nabożeństwo trwało zazwyczaj pół godziny. W niedziele i święta półtorej godziny później chłopcy schodzili się ponownie do kaplicy na dodatkowe egzorty, a wieczorem na adorację Najświętszego Sakramentu. Największe uroczystości były powodem do dłuższej, śpiewanej mszy i przedłużonego nabożeństwa ${ }^{61}$.

Wychowawcy chyrowscy przekonani byli o wielkiej sile wychowawczej modlitwy i rachunku sumienia. Obowiązkiem każdego konwiktora był zatem nie tylko pacierz poranny i wieczorny na klęczkach przy łóżku, ale także wspólna, trzyminutowa, głośna modlitwa rano w sali naukowej. Modlono się również przed i po każdym posiłku, przed i po nauce szkolnej i pozaszkolnej oraz ponownie wieczorem w sali naukowej. Zachęcano też do dodatkowych, indywidualnych modlitw w kaplicy i częstej spowiedzi. Raz w miesiącu klasowy prefekt prowadził z chłopcami „publiczną spowiedź” połączoną $\mathrm{z}$ rachunkiem sumienia, po której następowała ostra krytyka charakterów, zachowania i osiąganych wyników w nauce ${ }^{62}$.

Różnego rodzaju modlitwy odmawiano około dwudziestu razy dziennie. Wielu konwiktorów boleśnie odczuwało to jako przerost i przymus prowadzący do zakłamania i cynizmu. Jezuici tradycyjnie głosili, że obyczajowe udoskonalenie, które jest celem wychowania, logicznie oprzeć się może tylko na religii ${ }^{63}$, a celem ich pedagogiki jest wszczepienie podopiecznym wiary $i$ zasad katolickich $i$ wyrobienie cnót z zasad tych wynikających, tj. bojaźni Bożej, sumienności, zamiłowania pracy w różnych kierunkach, a tem samem uchronienie ich, o ile możności, od zapatrywań przewrotnych $i$ od wystepków, na jakie wiek młody bywa narażony ${ }^{64}$. Niestety, stosowane ku temu środki częstokroć wypaczały młode charaktery, wiodąc do dwulicowości czy konformizmu ${ }^{65}$.

Wśród wychowanków jezuickich opinie na temat praktyk religijnych są mocno podzielone ${ }^{66}$. Szczególnej jednak wymowy nabiera wzmianka o powodach, dla których jed-

${ }^{60}$ Podobnie było aż do 1938 r. w Kalksburgu. 100 Jahre Kollegium Kalksburg....

61 J. Niemiec, op. cit., s. 267-271. Zob. też wspomnienia ucznia Władysława Jagiełły w: Gimnazjum Ojców Jezuitów..., s. 50.

62 J. Starnawski, op. cit., s. 54.

${ }^{63}$ K. Krokoszyński, Wychowawcza praca Chyrowskiego Zakładu, w: Księga pamiątkowa pięćdziesięciolecia Konwiktu i Gimnazjum OO. Jezuitów w Chyrowie 1886-1936, Kraków 1936, s. 56.

${ }^{64}$ Deklaracje takie znajdujemy w wielu źródłach. Zob. np: Kolegium św. Józefa. Zakład wychowawczy $i$ naukowy Towarzystwa Jezusowego $w$ Chyrowie, [Stara Wieś 1888], s.1; Program Zakładu wychowawczo-naukowego pod wezwaniem św. Józefa w Bąkowicach pod Chyrowem, Przemyśl 1898, s. 1; Program Zakładu naukowo-wychowawczego OO. Jezuitów pod wezwaniem św. Józefa w Bąkowicach pod Chyrowem, Chyrów 1938, s. 1; Pamiętnik Chyrowski, Kraków 1903, s. XVII.

65 J. Kirchmayer, Pamiętniki, Warszawa 1962, s. 73-90; T. Włodarczyk, op. cit., s. 157-189.

${ }^{66}$ Autorzy wspomnień drukowanych w okolicznościowych wydawnictwach jezuickich mówią na ten temat z dużą aprobatą, zob. Księga pamiątkowa pięćdziesięciolecia..., passim; Chyrowiacy, passim. 
ną z ulubionych postaci Chyrowa był o. Włodzimierz Żukotyński - odprawiał mszę św. w rekordowo krótkim czasie ${ }^{67}$.

Profesorowie i prefekci Towarzystwa wielką wagę przywiązywali do kwestii natury obyczajowej, wszędzie doszukując się zgorszenia. Bardzo dociekliwie wypytywali chłopców „o różne sprawy [...] doczesnego żywota”, mimo że niektórzy niezbyt dobrze wiedzieli, o co w ogóle chodzi ${ }^{68}$. Poza konfesjonałem próbowali rozmawiać ze swoimi penitentami na tematy seksualne, a podczas rekolekcji przestrzegali, że jednym z największych zagrożeń w życiu młodego człowieka jest kobieta ${ }^{69}$. Konsekwencje takiego przeczulenia były, oczywiście, różne. Autorem skandalizującej sztuki scenicznej Fräulein Doktor jest przecież absolwent Chyrowa, Jerzy Tepa ${ }^{70}$.

W procesie wychowawczym stosowanym wobec konwiktorów wileńskich brakowało specjalnych rygorów, odbiegajacych od ogólnie przyjętych w tym czasie metod. Dotyczyto to zarówno uczniów dochodzacych do szkoty, jak i stale zamieszkujacych w czasie roku szkolnego w budynku znajdujacym się na terenie Zakonu. [...] Mury klasztorne nie stanowity przeszkody w przenoszeniu niektórych świeckich zwyczajów ogólnie przyjętych $w$ środowisku rodzinnym swych podopiecznych $[\ldots]^{71}$. Jednym z takich zwyczajów były zabawy szkolne z udziałem dziewcząt - całkowicie nie do pomyślenia w Chyrowie. Władze wileńskiej placówki wyznawały bowiem zasadę, że młodzież należy przygotować do sytuacji życiowych, z którymi bez wątpienia zetknie się po opuszczeniu murów szkoły.

Prawdopodobnie na stanowisko takie miał wpływ wielkomiejski charakter Wilna i obecność w nim innych, równie świetnych gimnazjów. Dobrze pojęta dyscyplina stała się tu źródłem poczucia bezpieczeństwa i komfortu psychicznego. Pozwalała na budowanie własnej autonomii w obrębie pewnych granic i jasno wyznaczonych reguł.

W Chyrowie starano się zaprowadzić porządek ,metodą złamania oporu bardziej samodzielnie odczuwających i myślących jednostek"72. Ośmieszano i poniżano w oczach kolegów, piętnując publicznie. Dla wielu wychowanków „,cała operacja tchnęła średniowieczem i wstrząsała [...] młodymi duszami"73. Bardzo cierpiała na tym ambicja chłopców, ale dla własnego dobra starali się wszystko to znosić i unikać kar ${ }^{74}$. Trzeba zarazem podkreślić, że rodzice na ogół aprobowali taki system, a i liczni absolwenci po latach wykazywali dlań zrozumienie ${ }^{75}$.

\footnotetext{
67 J. Garliński, op. cit., s.63.

68 Ibidem, s.61.

${ }^{69}$ S. Moysa, Ze wspomnień bylego chyrowiaka jezuity, w: Chyrowiacy, s. 70-71.

${ }^{70}$ Tepa Jerzy, w: Stownik współczesnych pisarzy polskich, t. 3: R-Ż, s. 343-344; Tepa Jerzy, w: Chyrowiacy, s. 568.

71 Posłowie [do:] Wspomnienia uczniów, w: Gimnazjum Ojców Jezuitów..., s. 288.

72 Ibidem, s. 60; A. Paygert, op. cit., s. 74.

73 J. Garliński, op. cit., s. 60.

${ }^{74}$ J. Starnawski, op. cit., s. 48.

75 „Nasi opiekunowie wykazywali ze swej strony wiele poświęcenia, może nawet uczucia. Posiadali znaczne umiejętności w kierowaniu i wychowaniu młodzieży, mimo że czasem wykazywali dziwny upór, gdy chodzi o niektóre poglądy czy metody wychowawcze.” J. Starnawski, op. cit., s. 50. Zob. też: L. Dworak, Wiara $w$ potęge modlitwy, w: Chyrowiacy, s. 41; Z. T. Martynowski, Co zawdzięczam Chyrowowi?, ibidem, s. 32; W. Krawczyński, op. cit., s. 65.
} 
Pobyt w oddalonym od domu rodzinnego, czasem o wiele kilometrów, surowym konwikcie młodym ludziom wydawał się początkowo katorgą ${ }^{76}$. Swych wychowawców uważali za „aparat ucisku" 77 , ale z perspektywy czasu wspominali placówkę i panujący w niej system wychowawczy jako twardy sposób hartowania charakterów ${ }^{78}$. Godzili się z nim i podporządkowywali, a potem mówili o nim z uznaniem, szczególnie ci, którzy wynieśli z domów rodzinnych tożsamy z jezuickim system poglądów i wartości. Członkowie Towarzystwa Jezusowego umocnieni przekonaniem o istnieniu przyzwolenia na realizację własnej oferty edukacyjnej, mniej lub bardziej skutecznie naginali młode charaktery pełni takiej samej wiary, jak bohater Philopatera, dowodzący, że „,zasady etyczne przyswojone w młodości [...] szczególnie ważne są dla ludzi, którzy mają kierować drugimi i przejąć na siebie większe ciężary i obowiązki"

Przyszłym liderom życia publicznego jezuici stworzyli luksusowe warunki bytowe, zapewniając ,pomoc w wyrabianiu sprawności duchowych”. Towarzyszący chłopcom przez cały dzień profesorowie i prefekci starli się w salach lekcyjnych i w konfesjonale, podczas egzort i w zwykłych rozmowach wskazywać jedynie słuszny, ich zdaniem, system poglądów i wartości. Nie kryli się też ze swymi sympatiami politycznymi ${ }^{80}$. Choć konwiktowe Ustawy głosiły, że w hierarchii celów edukacyjnych naczelne miejsce zajmuje dobro kraju, hasłem wychowanków - „Związku Byłych Chyrowiaków” zostało Deo, Patriae, Amicitiae. Całkowicie zgodne z planem „pozyskania dla wyższych celów Kościoła katolickiego zastępu oddanych mu ludzi”»1.

\footnotetext{
${ }^{76}$ W. Krawczyński, op. cit., s. 64.

77 S. Moysa, op. cit., s. 70.

78 I. Hirszel, op. cit., s. 27; J. Starnawski, op. cit., s. 49.

${ }^{79}$ L. Winniczuk, op. cit., s. 238.

${ }^{80}$ J. Garliński, op. cit., s. 60; J. Starnawski, op. cit., s. 58.

81 J. Kirchmayer, op. cit., s. 87.
} 